\title{
STRATEGI PIMPINAN DALAM PENINGKATANBUDAYA KERJA DI PERGURUAN TINGGI
}

\author{
Noer Rohmah \\ e-mail: noerrohmah@yahoo.com \\ Sekolah Tinggi Ilmu Tarbiyah (STIT) Ibnu Sina Kabupaten Malang
}

\begin{abstract}
The college is one of the dominant social institutions and the effect on the culture of a nation is also responsible for the transmission of culture from one generation to another as well as preservation. Universities at this time to be ready to face the challenges of globalization and produce graduates who can compete and fill the global era. For that universities must be able to become an institution that global perspective as well as the resources of international standard. Therefore, it is necessary to change the mindset of college becomes mindset following the change, which is oriented on creating a work culture that is more dynamic, productive, and competitive. As for some of the strategies that can be taken by the leadership for the improvement of work culture to make it more dynamic and competitive of them are; (1) creating a smart cultural organization, (2) build employee morale order dynamic competition, (3) improve emotional intelligence in building relationships work, and (4) improve communication in relationships creating work team.
\end{abstract}

Keywords: strategy, improvement of work culture

\section{Abstrak}

Perguruan tinggi merupakan salah satu institusi sosial yang dominan dan berpengaruh pada kebudayaan suatu bangsa juga bertanggung jawab dalam transmisi budaya dari satu generasi ke generasi lain serta pelestariannya. Perguruan tinggi saat ini harus siap menghadapi tantangan globalisasi dan menghasilkan lulusan yang dapat bersaing dan mengisi era global. Untuk itu perguruan tinggi harus mampu menjadi institusi yang berwawasan global serta memiliki sumber daya berstandar internasional. Oleh karena itu perlu adanya perubahan pola pikir perguruan tinggi menjadi pola pikir yang mengikuti perubahan, yang berorientasi pada penciptaan budaya kerja yang lebih dinamis, produktif, dan kompetitif. Adapun beberapa strategi yang bisa ditempuh oleh pimpinan untuk peningkatan budaya kerja agar lebih dinamis dan kompetitif diantaranya adalah; (1) menciptakan organisasi yang cerdas budaya, (2) membangun Karyawan agar memiliki semangat kompetisi yang dinamis, (3) meningkatkan kecerdasan emosi dalam membangun hubungan kerja, dan (4) meningkatkan komunikasi dalam menciptakan hubungan tim kerja.

Keywords: strategi, peningkatan budaya kerja

\section{Pendahuluan}

Perguruan tinggi adalah bagian tidak terpisahkan dalam kerangka menciptakan kecerdasan berbangsa dan bernegara. Perguruan tinggi dengan Tri Dharma perguruan tinggi yakni Pendidikan, Penelitian dan Pengabdian masyarakat, menjadi kekuatan untuk melahirkan alumni-alumni yang memiliki kompetensi atau skill, sikap dan pengetahuan yang mampu bermanfaat dalam dunia kerja maupun masyarakat banyak. Tujuan dan arah Pendidikan Tinggi di Indonesia seperti yang 
tertuang pada Bab II pasal 2. Keputusan Menteri Pendidikan No.232/U/2000 adalah menyiapkan peserta didik untuk menjadi anggota masyarakat yang memiliki kemampuan akademik dalam menerapkan, mengembangkan, dan/atau memperkaya hasanah ilmu pengetahuan, teknologi dan atau kesenian, serta menyebarluaskan dan mengupayakan penggunaannya untuk meningkatkan taraf kehidupan dan memperkaya kebudayaan nasional (Keputusan Mentri Pendidikan Nasional Republik Indonesia No. 232/U/2000 tentangPedomanPenyusunan Kurikulum Pendidikan Tinggi danPenilaian BelajarMahasiswa).

Era globalisasi senantiasa menghadirkan perubahan-perubahan yang menyebabkan pola pikir dan pola hidup masyarakat sekarang turut berubah untuk melakukan penyesuaian. Dalam dunia pendidikan, perubahan-perubahan itu harus dihadapi oleh para pimpinan pendidikan melalui strategi tertentu. Agar dapat mewujudkan lulusan yang mampu bersaing di ranah global, Salah satu hal untuk mewujudkan hal tersebut adalah budaya kerja perguruan tinggi yang mumpuni, yang mampu mendukung dan menyiapkan mahasiswa menjawab tantangan dan mengisi era globalisasi ini.

Keberhasilan di era globalisasi, menurut Soehendro ditentukan oleh produktivitas, efisiensi dalam bekerja (Soehendro, 1996: 1). Modal penggeraknya sumber daya manusia (SDM) berkualitas yang dihasilkan dari perguruan tinggi terbaik. Keberhasilan perguruan tinggi dalam menghasilkan SDM berkualitas dapat dilakukan bila dosennya memiliki pengetahuan, keterampilan, sikap, tingkah laku baik, handal, profesional guna mendorong terlaksananya fungsi tridharma perguruan tinggi, yaitu pendidikan \& pengajaran, penelitian serta pengabdian pada masyarakat.

Kasali menyatakan pengembangan budaya kerja dosen, mengisyaratkan pimpinan kampus untuk terus melakukan perubahan yang mencerminkan tuntutan baru dalam masyarakat karena dari situlah elite bangsa dihasilkan. Kalau dunia usaha berubah, melakukan pembenahan budaya kerja tapi dunia pendidikan jalan di tempat maka celaka suatu Negara. Untuk itu reformasi budaya kerja di perguruan tinggi perlu dilakukan pimpinannya (Rhenal, $2010: 31$ ).

Pengembangan budaya kerja dosen maupun karyawan menjadi penting dilakukan. Karena budaya kerja dosen berperan sebagai katalisator \& inhibitor proses kerja perguruan tinggi. Budaya kerja dosen merupakan strategi bagi setiap perguruan tinggi yang ingin survive dan unggul di arena nasional maupun global, untuk itu dalam kepemimpinan rektor perlu memiliki komitmen menjadikan perguruan tinggi yang dimpinnya menjadi world class University (WCU). Karena kepemimpinan seseorang dalam sebuah lembaga apalagi perguruan tinggi mempunyai peran penting dalam membangun dan mengembangkan budaya kerja di lembaga tinggi tersebut. Budaya kerja dalam sebuah perguruan tinggi akan memberikan seperangkat norma yang dibutuhkan anggota organisasi. Sehingga budaya kerja dapat memberikan pemaknaan yang kuat terhadap apa yang dilakukan para dosen, mahasiswa dan karyawan di perguruan tinggi tersebut.

\section{Konsep Dasar Tentang Budaya Kerja 1. Pengertian Budaya Kerja}

Budaya kerja menurut Hadari Nawawi adalah kebiasaan yang dilakukan berulang-ulang oleh pegawai dalam suatu organisasi, pelanggaraan terhadap kebiasaan ini memang tidak ada sangsi tegas, namun dari pelaku organisasi secara moral telah menyepakati bahwa kebiasaan tersebut merupakan kebiasaan yang harus ditaati dalam rangka pelaksanaan pekerjaan untuk mencapai tujuan (Nawawi, 2003: 65).

$\begin{array}{ccc}\text { Adapun Menurut } & \text { Triguno dalam } \\ \text { bukunya Manajemen } & \text { Sumber } & \text { Daya }\end{array}$


Manusia menerangkan bahwa: Budaya kerja adalah suatu falsafah yang didasari oleh pandangan hidup sebagai nilai-nilai yang menjadi sifat, kebiasaan, dan kekuatan pendorong, membudaya dalam kehidupan suatu kelompok masyarakat atau organisasi yang tercermin dari sikap menjadi perilaku, kepercayaan, cita-cita, pendapat dan tindakan yang terwujud sebagai kerja atau bekerja (Triguno, 2001: 13). Taliziduhu Ndraha dalam buku Teori Budaya Kerja, mendefinisikan budaya kerja, yaitu; "sekelompok pikiran dasar atau program mental yang dapat dimanfaatkan untuk meningkatkan efisiensi kerja dan kerjasama manusia yang dimiliki oleh suatu golongan masyarakat" (Ndraha, 2002: 80).

Budaya Kerja itu sudah lama dikenal oleh umat manusia, namun belum disadari bahwa suatu keberhasilan kerja itu berakar pada nilai-nilai yang dimiliki dan perilaku yang menjadi kebiasaannya. Nilai-nilai yang telah menjadi kebiasaan tersebut dinamakan Budaya. Oleh karena budaya tersebut dikaitkan dengan mutu/kualitas kerja, maka dinamakan Budaya Kerja.Budaya Kerja dapat diwujudkan setelah melalui proses yang panjang. Hal ini dikarenakan perubahan nilai-nilai lama menjadi nilai-nilai baru akan memakan waktu untuk menjadi kebiasaan dan tak henti-hentinya terus melakukan penyempurnaan dan perbaikan. Produktivitas Dalam hal ini dapat dilihat kaitan antara kepribadian dan hasil kerja di mana di dalam kepribadian terkandung unsur bakat, keterampilan, minat, sifat, gairah, dan nilai-nilai. Kepribadian tersebut menjadi sikap, kemudian menjadi perilaku yang mengandung unsur semangat, disiplin, rajin, jujur, tanggung jawab, hemat, integritas; sehingga hasil kerja akan mencapai kualitas yang tinggi atau memuaskan (Koentjaraningrat, 1974:45).

\section{Fungsi, Tujuan, dan Manfaat Budaya Kerja}

Setiap organisasi mempunyai kebudayaan . Dan kebudayaan dapat menjadi kekuatan, baik positif maupun negatif dalam mencapai prestasi secara efektif. Dengan mengutip pendapat Peters dan Waterman, Imam Mudjiono mengatakan bahwa organisasi yang efektif itu mempunyai kebudayaan internal. Organisasi bisa menjadi kuat berkat adanya mutu yang sangat baik dari organisasi itu sendiri (Moedjiono, 2002: 141). Jika budaya kerja dalam sebuah organisasi atau lembaga pendidikan termasuk perguruan tinggi itu mengedepankan kedisiplinan, kreativitas, kerja sama, kesetaraan, dan lahirnya ideide segar yang inovatif, maka dalam waktu tidak lama organisasi akan mengalami peningkatan yang signifikan. Akan tetapi jika organisasi melakukan toleransi terhadap ketidakdisiplinan, konflik serta dominasi, maka organisasi akan berjalan secara stagnan dan dekaden. Kerja dapat menjalankan sejumlah fungsi dalam sebuah organisasi. Pertama, budaya kerja mempunyai satu peranan dalam menetapkan tapal batas, artinya budaya kerja akan menciptakan pembedaan yang jelas antara organisasi yang satu dengan organisasi yang lainnya. Kedua, budaya kerja akan membawa suatu rasa identitas bagi anggota-anggota organisasi. Ketiga, budaya kerja akan mempermudah timbulnya komitmen pada sesuatu yang lebih luas daripada kepentingan diri pribadi seseorang (Triguno, 1999:56) .

Tujuan fundamental dari Budaya Kerja adalah untuk membangun sumber daya manusia seutuhnya agar setiap orang sadar bahwa mereka berada dalam suatu hubungan sifat peran sebagai pelanggan, pemasok, dan komunikasi dengan orang lain secara efektif dan efisien serta menggembirakan. Oleh karenanya, Budaya Kerja berupaya mengubah budaya komunikasi tradisional menjadi perilaku manajemen modern, sehingga tertanam kepercayaan dan semangat kerja sama yang tinggi serta disiplin. Hal ini tentunya akan mengakibatkan produktivitas kerja semakin meningkat. 
Suatu organisasi yang memiliki Budaya Kerja yang kuat akan dapat memperoleh hasil yang lebih baik, hal ini dikarenakan para pekerja atau pegawainya telah mengetahui dan memahami akan "Pekerjaan apa yang harus dilakukan dan bagaimana cara menyelesaikan pekerjaan tersebut" (what to do and how to do it). Dengan demikian dapat dikatakan bahwa tujuan budaya kerja itu adalah ( Subianto, $2000: 22-23$ ): (1) meningkatkan kualitas hasil kerja; (2) meningkatkan kualitas pelayanan; (3) menciptakan budaya kualitas; (4) meningkatkan profesionalitas; dan (5) mengurangi kelemahan birokrasi (Triguno, 1999 : 77).

Manfaat yang diharapkan dari penerapan budaya kerja dalam suatu pekerjaan antara lain sebagai berikut:

a. Menjamin hasil kerja dengan kualitas yang baik.

b. Keterbukaan antara para individu dalam melakukan pekerjaan.

c. Saling bergotong royong apabila dalam suatu pekerjaan ada masalah yang sulit.

d. Menimbulkan rasa kebersamaan antara individu dengan individu lain dalam pekerjaan.

e. Cepat menyesuaikan diri dengan perkembangan yang terjadi di dunia luar

f. Membuka seluruh jaringan komunikasi, kegotongroyongan, kekeluargaan, sehingga cepat menemukan dan memperbaiki kesalahan dan cepat menyesuaikan diri dengan perkembangan dari luar;

g. Mengurangi laporan berupa datadata dan informasi yang salah dan palsu.(Teknologi, Masyarakat, Sosial, Ekonomi dll.) ( Subianto, $2000: 89$ ).

Manfaat lainnya yang dapat muncul antara lain kepuasan kerja meningkat, pergaulan yang lebih akrab, disiplin meningkat, pengawasan fungsional berkurang, tingkat absensi turun, keinginan belajar yang tinggi, keinginan memberikan yang terbaik bagi organisasi, dan lain-lain. Lebih jauh, Roland E. Wolseley dan Laurence R. Campbell dalam bukunya Exploring Journalism menyatakan bahwa:

a. Orang yang terlatih dalam kelompok budaya kerja akan memecahkan permasalahan secara mandiri dengan bantuan keahliannya berdasarkan metode ilmu pengetahuan, dibangkitkan oleh pemikiran yang kritis, kreatif, tidak menghargai penyimpangan akal bulus dan pertentangan.

b. Orang yang terdidik melalui kelompok budaya kerja akan berusaha menyesuakan diri antara kehidupan pribadinya dengan kebiasaan sosialnya, baik nilai nilai spiritual maupun standar-standar etika yang fundamental untuk menyerasikan kepribadian dan moral karakternya.

c. Orang yang terdidik dalam kelompok budaya kerja akan mempersiapkan dirinya dengan pengetahuan umum dan keahliankeahlian khusus dalam mengelola tugas atau kewajibannya dalam bidangnya, demikian pula dalam hal berproduksi dan pemenuhan kebutuhan hidupnya.

d. Orang yang terlatih dalam kelompok budaya kerja akan memahami dan menghargai lingkungannya

e. Budaya kerja membentuk perilaku staf dengan mendorong percampuran core values dan perilaku yang diinginkan, sehingga memungkinkan organisasi bekerja dengan lebih efisien dan efektif, meningkatkan konsistensi, menyeleseikan konflik dan menfasilitasi koordinasi dan control.

f. Budaya kerja akan meningkatkan motivasi staf dengan memberi mereka perasaan memiliki, loyalitas, kepercayaan, dan nilai-nilai, dan mendorong mereka berpikir positif tentang mereka dan organisasi. Dengan demikian, organisasi dapat memaksimalkan potensi stafnya dan 
memenangkan kompetisi ( Nawawi, $2013 ; 15$ ).

\section{Model Budaya Kerja}

Model budaya kerja berdasarkan kajian-kajian yang dilakukan mengenai budaya kerja organisasi telah menampilkan beberapa model tertentu yaitu budaya autoritarian, budaya birokratik, budaya tugas, budaya individualistik, budaya tawar-menawar dan budaya kolektif.

a. Budaya kerja autoritarian

Budaya kerja jenis ini menumpukan kepada command and control. Kuasa dan autoriti dalam organisasi biasanya terpusat kepada pemimpinnya yang seringkali disanjung sebagai pahlawan.Pekerja akan diharapkan untuk memperlihatkan kesetiaan yang tinggi kepada pemimpin. Arahan dan peraturan dihantar dari atas menuju ke dasar organisasi.

Dengan demikian hubungan personal yang rapat dengan pihak atasan adalah faktor penting dalam kelancaran pekerjaan dan kenaikan pangkat. Oleh itu bagi menjaga kepentingan, pekerja cenderung bersikap yes man dan play safe daripada memberi pandangan kritikal bagi menjaga kedudukan dan kepentingan masing-masing.

b. Budaya kerja birokratik

Budaya kerja birokratik ini berasaskan kepada konsep bahawa organisasi boleh diurus dengan cakap menerusi kaedah pengurusan bersifat impersonal, rasional, autoriti dan formaliti. Impersonal bermaksud setiap pekerja tertakluk kepada peraturan dan prosedur yang sama dan harus menerima layanan yang sama. Peraturan dan prosedur tersebut adalah dilaksanakan secara formal untuk mengingatkan pekerja akan etika dan keperluan yang dikehendaki daripada mereka.

c. Budaya kerja fungsional
Organisasi-organisasi kerja yang berjaya di Barat sering mengamalkan budaya kerja fungsional atau project-based ini. Dalam konsep fungsional, kerja dalam organisasi dibagi dan ditugaskan kepada individu atau pasukan tertentu. Projek yang paling penting akan diserahkan kepada pekerja atau sekumpulan pekerja yang paling berkemampuan. Apabila projek tersebut selesai, maka tugas individu atau kumpulan akan selesai dan kumpulan baru pula akan dibentuk bagi melaksanakan projek yang lain. Oleh itu, struktur kumpulan adalah fleksibel dan interaksi adalah berasaskan kemahiran dan hormatmenghormati.

d. Budaya kerja individualistik

Dalam organisasi yang mengamalkan budaya kerja ini, individu tertentu menjadi tumpuan utama. Terdapat universiti yang bergantung kepada profesor ternama untuk menarik pelajar dan mendapatkan tujuan. Dalam organisasi seperti ini segelintir kecil pekerja adalah tulang belakang kejayaan syarikat kerena mereka mempunyai reputasi, kredibiliti, kepandaian dan keterampilan. Kebolehan mendapatkan pelanggan seringkali menyebabkan mereka kurang terikat kepada peraturan dan prosedur. Kenaikan pangkat sepenuhnya bergantung kepada meritokrasi kerana setiap orang perlu membuktikan bahawa mereka memberi sumbangan yang lebih daripada orang lain kepada organisasi.

e. Budaya kerja tawar-menawar

Dalam organisasi jenis ini, kesatuan sekerja berfungsi untuk menjaga kepentingan pekerja dan membantu pengurusan mencapai matlamat organisasi. Perundingan dan tawar menawar berlangsung berdasarkan perundangan dan prosedur yang diakui oleh kedua-dua belah pihak. 
Meskipun pertikaian dan pertentangan pendapat kadangkala berlaku antara kesatuan sekerja dan majikan, tetapi ia sering dapat diselesaikan di meja rundingan. Dari satu segi pihak pengurusan boleh mendapat pandangan wakil kesatuan sekerja bagi melaksanakan peraturan, sistem dan ganjaran. Manakala kesatuan sekerja akan mempastikan hak, kepentingan dan kebajikan pekerja diberi jaminan. Secara keseluruhannya pendekatan ini yang berkonsepkan hubungan rapat majikan pekerja bertujuan untuk mewujudkan situasi menangmenang antara kedua belah pihak.

f. Budaya kerja kolektif

Dikatakan bahawa antara kunci kejayaan organisasi Jepun adalah kebolehan mereka untuk menggunakan idea dan cadangan pekerja bawahan. Ini karena pekerja adalah 'pemilik proses kerja' dan mereka lebih mengetahui tentang sistem dan tatacara melaksanakan kerja berbanding orang lain. Dengan itu pekerja diberi peluang untuk mengemukakan cadangan dan kreativitas bagi memperbaiki proses kerja, sistem dan prosedur ( Ndraha, $2002: 25$ ).

\section{Pengembangan Budaya Kerja di Perguruan Tinggi}

Keberadaan perguruan tinggi merupakan salah satu pertanda peradaban suatu masyarakat. Masyarakat yang berperadaban cenderung mengembangkan berbagai institusi yang mampu menggali, mengembangkan, mengalihkan, dan menerapkan pengetahuan yang diperlukan untuk memajukan masyarakat tersebut. Dalam hal ini, perguruan tinggi adalah institusi yang mempunyai kedudukan terpenting. Dengan demikian perguruan tinggipengembangan pengetahuanpembangunan masyarakat merupakan suatu mata rantai yang tidak dapat dipisahkan ( Sonhadji, 2012 : 116 ).
Dalam perkembangan berikutnya dapat kita lihat ada keterkaitan antara budaya dengan disain organisasi atau hubungan budaya dengan keberhasilan suatu perguruan tinggi sesuai dengan design culture yang akan diterapkan. Untuk memahami disain organisasi tersebut, Harrison membagi empat tipe budaya kerja dalam organisasi antara lain yaitu ( Handy, 2002 : 65-66) :

a. Budaya kekuasaan (Power culture).

Budaya ini lebih memfokuskan sejumlah kecil pimpinan menggunakan kekuasaan yang lebih banyak dalam cara memerintah. Budaya kekuasaan juga dibutuhkan dengan syarat mengikuti esepsi dan keinginan anggota suatu organisasi.

Seorang dosen, seorang guru dan seorang karyawan butuh adanya peraturan dan pemimpin yang tegas dan benar dalam menetapkan seluruh perintah dan kebijakannya. Kerena hal ini menyangkut kepercayaan dan sikap mental tegas untuk memajukan institusi organisasi. Kelaziman diinstitusi pendidikan yang masih menganut manajemen keluarga, peranan pemilik institusi begitu dominan dalam pengendalian sebuah kebijakan institusi akademis, terkadang melupakan nilai profesionalisme yang justru hal inilah salah satu penyebab jatuh dan mundurnya sebuah perguruan tinggi.

\section{b. Budaya peran (Role culture)}

Budaya ini ada kaitannya dengan prosedur birokratis, seperti peraturan organisasi dan peran/jabatan/posisi spesifik yang jelas karena diyakini bahwa hal ini akan menstabilkan sistem. Keyakinan dan asumsi dasar tentang kejelasan status/posisi/peranan yang jelas inilah akan mendorong terbentuknya budaya positif yang jelas akan membantu menstabilkan suatu organisasi. Bagi seorang dosen tetap jauh lebih cepat menerima seluruh kebijakan akademis daripada dosen terbang yang hanya sewaktu-waktu hadir sesuai dengan jadwal perkuliahan. Hampir semua orang 
menginginkan suatu peranan dan status yang jelas dalam organisasi.

Bentuk budaya ini kalau diterapkan dalam budaya akademis dapat dilihat dari sejauhmana peran dosen dalam merancang, merencanakan dan memberikan masukan (input) terhadap pembentukan suatu nilai budaya kerja tanpa adanya birokarasi dari pihak pimpinan. Jelas masukan dari bawah lebih independen dan dapat diterima karena sudah menyangkut masalah personal dan bisa didukung oleh berbagai pihak melalui adanya perjanjian psikologis antara pimpinan dengan dosen yang dibawahnya. Budaya peran yang diberdayakan secara jelas juga akan membentuk terciptanya profesionalisme kerja seorang dosen dan rasa memiliki yang kuat terhadap peran sosialnya di kampus serta aktifitasnya diluar kegiatan akademis dan kegiatan penelitian.

c. Budaya Pendukung (Support culture)

Budaya yang didalamnya ada kelompok atau komunitas yang mendukung seseorang yang mengusahakan terjadinya integrasi dan seperangkat nilai bersama dalam organisasi tersebut. Selain budaya peran dalam menginternalisasikan suatu budaya perlu adanya budaya pendukung yang disesuaikan dengan kredo dan keyakinan anggota dibawah. Budaya pendukung telah ditentukan oleh pihak pimpinan ketika organisasi/institusi tersebut didirikan oleh pendirinya yang dituangkan dalam visi dan misi organisasi tersebut. Jelas didalamnya ada keselaran antara struktur, strategi dan budaya itu sendiri. Dan suatu waktu bisa terjadi adanya perubahan dengan menanamkan budaya untuk belajar terus menerus (longlife education)

\section{d. Budaya Prestasi (Achievement culture) \\ Budaya yang didasarkan pada} dorongan individu dalam organisasi dalam suasana yang mendorong eksepsi diri dan usaha keras untuk adanya independensi dan tekananya ada pada keberhasilan dan prestasi kerja. Budaya ini sudah berlaku dikalangan akademisi tentang independensi dalam pengajaran, penelitian dan pengabdian serta dengan pemberlakuan otonomi kampus yang lebih menekankan terciptanya tenaga akademisi yang profesional, mandiri dan berprestasi dalam melaksanakan tugasnya.

Empat tipe budaya diatas cukup mengena dalam kaitannya dengan pengaruh budaya terhadap kinerja seorang dosen dapat dilihat dari budaya prestasi atau lebih tepat sebagai bentuk profesionalisme seorang dosen dalam perannya, dimana Handi menyebutnya dengan istilah budaya pribadi (person culture). ( Handy, 2002 : 66).

Selanjutnya Kotter \& Hesket juga mengatakan bahwa budaya kerja dalam organisasi berawal dari gagasan manajemen puncak yang diwujudkan menjadi filosofi, visi dan strategi. Filosofi, visi, dan strategi tersebut diimplementasikan pada perilaku organisasi. Perilaku organisasi tersebut akan membentuk budaya organisasi yang dilakukan oleh anggota organisasi untuk mencapai tujuan yang telah ditetapkan. Proses ini dapat diilustrasikan pada gambar berikut:

\section{Gambar Proses Pembentukan Budaya dari Top Manajer}

\section{MANAJEMEN PUNCAK}

Manajer puncak mengembangkan dan berusaha mengimplementasikan filosofi, visi atau strategi

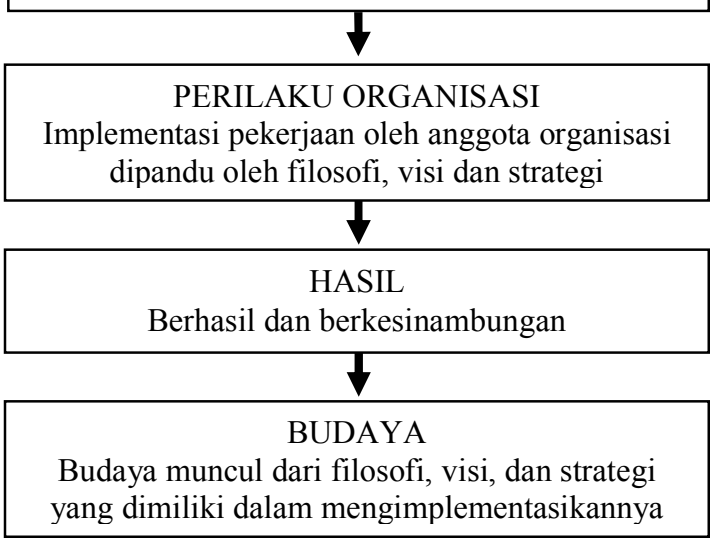


Seorang pemimpin, baik pemimpin puncak atau menengah, mempunyai peran utama untuk membangun moral kerja dan produktivitas para dosen, mahasiswa dan karyawan di lembaganya. Pimpinan memberikan pemahaman yang kuat kepada semua anggota organisasi tentang visi misi lembaga sehingga hal tersebut dapat dimanifestasikan dalam bentuk nilai, keyakinan dan perilaku organisasi sehari-hari.

Dalam dunia pendidikan mengistilahkan budaya dalam organisasi dengan istilah Kultur akademis yang pada intinya mengatur para pendidik agar mereka memahami bagaimana seharusnya bersikap terhadap profesinya, beradaptasi terhadap rekan kerja dan lingkungan kerjanya serta berlaku reaktif terhadap kebijakan pimpinannya, sehingga terbentuklah sebuah sistem nilai, kebiasaan (habits), citra akademis, ethos kerja yang terinternalisasikan dalam kehidupannya sehingga mendorong adanya apresiasi dirinya terhadap peningkatan prestasi kerja baik terbentuk oleh lingkungan organisasi itu sendiri maupun dikuatkan secara organisatoris oleh pimpinan akademis yang mengeluarkan sebuah kebijakan yang diterima ketika seseorang masuk organisasi tersebut.

Fungsi pimpinan sebagai pembentuk Kultur akademis diungkapkan oleh Peter, Dobin dan Johnson bahwa :

Para pimpinan sekolah khususnya dalam kapasitasnya menjalankan fungsinya sangat berperan penting dalam dua hal yaitu : a). Mengkonsepsitualisasikan visi dan perubahan dan b). Memiliki pengetahuan, keterampilan dan pemahaman untuk mengtransformasikan visi menjadi etos dan kultur akademis kedalam aksi riil . ( Danim, 2003 : 74)

Jadi terbentuknya Kultur akademis bisa dicapai melalui proses transformasi dan perubahan tersebut sebagai metamorfosis institusi akademis menuju kultur akademis yang ideal. Budaya itu sendiri masuk dan terbentuk dalam pribadi seorang dosen itu melalui adanya adaptasi dengan lingkungan, pembiasaan tatanan yang sudah ada dalam etika pendidikan ataupun dengan membawa sistem nilai sebelumnya yang kemudian masuk dan diterima oleh institusi tersebut yang akhirnya terbentuklah sebuah budaya akademis dalam sebuah organisasi.

Pola pembiasaan dalam sebuah budaya sebagai sebuah nilai yang diakuinya bisa membentuk sebuah pola prilaku dalam hal ini Ferdinand Tonniesmembagi kebiasaan kedalam beberapa pengertian antara lain :

a) Kebiasaan sebagai suatu kenyataan objektif sehari-hari yang merupakan sebuah kelajiman baik dalam sikap maupun dalam penampilan seharihari. Seorang pendidik sebagai profesionalis biasa berpenampilan rapi, berdasi dan berkemeja dan bersikap formal, sangat lain dengan melihat penampilan dosen institut seni yang melawan patokan formal yang berlaku didunia pendidikan dengan berpakaian kaos dan berambut panjang.

b) Kebiasaan sebagai Kaidah yang diciptakan dirinya sendiri yaitu kebiasaan yang lahir dari diri pendidik itu sendiri yang kemudian menjadi ciri khas yang membedakan dengan yang lainnya.

c) Kebiasaan sebagai perwujudan kemauan untuk berbuat sesuatu yaitu kebiasaan yang lahir dari motivasi dan inisatif yang mencerminkan adanya prestasi pribadi ( Soerjono, $2003: 174$ ).

\section{Strategi Pimpinan dalam Pengembangan Budaya Kerja di Perguruan Tinggi}

Strategi adalah sebuah rencana atau cetak biru untuk menjalankan misi dan mencapai sasaran strategis. Bagi organisasi bisnis maupun organisasi pendidikan, sebuah bagian utama dari strategi itu adalah bagaimana bersaing secara efektif di pasar dan tetap 
mendapatkan keuntungan. beberapa contoh kemungkinan strategi kopetitif meliputi berikut : menjual sebuah produk atau jasa dengan harga rendah, memiliki kualitas superior dengan harga yang sedang, memberikan sebuah produk atau jasa yang unik dalam sebuah segmen pasar yang diabaikan oleh organisasi yang bersaing ( strategi "ceruk "), memberikan pelayanan pelanggan yang luar biasa, memiliki produk atau jasa yang paling inovatif, dan menjadi organisasi yang paling fleksibel mengenai pengkhususan produk atau jasa untuk memenuhi kebutuhan setiap klien ( Yukl , 2010 : 430).

Adapun beberapa pedoman untuk memformulasikan strategi antara lain adalah:

1. Menentukan sasaran dan prioritas jangka panjang

2. Menilai kekuatan dan kelemahan saat ini

3. Mengenali kompetensi diri

4. Mengevaluasi kebutuhan akan perubahan besar dalam strategi

5. Mengenali strategi yang menjanjikan

6. Mengevaluasi kemungkinan hasil dari sebuah strategi

7. Melibatkan eksekutif lain dalam memilih sebuah strategi

Soenarjo juga menyatakan bahwa budaya kerja dapat terlaksana dengan baik, sesuai dengan harapan bila diawali dengan komitmen pimpinan puncak dan diikuti bawahan, sehingga seluruh civitas akademika perguruan tinggi melaksanakan budaya kerja dengan sepenuh hati.Pengembangan budaya kerja oleh pimpinan puncak harus mengutamakan aspek "achievement dan teamwork" tujuannya meningkatkan kepuasan pekerja, customers dan kinerja institusi keunggulan bersaing dengan institusi lain. Usaha itu berawal dari pembinaan visi, misi, dan nilai yang terdapat di dalam institusi, perilaku, sistem pengembangan sumber daya, dan kepemimpinan melakukan komunikasi secara intensif, komitmen yang kuat untuk mengembangkan budaya kerja ( Soenardjo : 2014 : 67 ).

Pengembangan budaya kerja oleh pimpinan perguruan tinggi, dapat dilakukan berupa a) berorientasi pada hasil kerja, b) komitmem untuk melakukan perbaikan terus-menerus, c) menekankan pentingnya kualitas kerja, d) fokus manajemen perlu dirubah ke arah pemenuhan kebetuhan pasar, proaktif, melihat ke depan, hari ini lebih baik dari kemaren, mendapatkan ide-ide dan cara baru, dukungan kuat untuk bekerjasama, e) nilai-nilai organisasipun ikut dirubah ke arah yang bisa dimengerti dengan jelas sesuai dengan strategi cita-cita institusi, f) kenaikan pangkat dan imbalan atas prestasi kerja, responsibility, accountability, loyalitas tinggi, kemauan untuk hal-hal baru, mengedepankan nilai universal.

Adapun beberapa strategi yang dapat digunakan oleh pimpinan dalam proses pengembangan budaya kerja antara lain adalah :

\section{Menciptakan Organisasi yang Cerdas Budaya}

Untuk dapat bertahan terhadap perubahan lingkungan yang terjadi, suatu organisasi harus mampu mengembangkan dirinya menjadi organisasi yang cerdas budaya. Suatu organisasi cerdas budaya adalah suatu organisasi yang mampu mensinergikan pengetahuan, kesadaran, dan keterampilan berperilaku. Pengembangan kecerdasan budaya terjadi dalam beberapa tahapan sebagai berikut ( Wibowo , 2013 : 63):

Tahap 1 : Reaktivitas terhadap stimuli eksternal. Sebagai titik awal adalah kesetiaan tanpa pertimbangan pada aturan dan norma budaya sendiri. Pada tahap ini tipikal individu sangat sedikit minat pada budaya lain.

Tahap 2 : Pengakuan terhadap norma budaya lain dan motivasi untuk belajar lebih banyak tentangnya. Keingintahuan tumbuh dan individu ingin lebih banyak belajar. Orang pada tahap ini berjuang memilih melalui kompleksitas 
lingkungan budaya. Mereka mencari aturan berdasarkan pengalaman untuk mengarahkan perilaku mereka.

Tahap 3 : Akomodasi terhadap norma dan aturan budaya lain dalam pikiran. Pemahaman lebih dalam tentang variasi budaya mulai dikembangkan. Pengakuan terhadap respons perilaku yang cocok untuk pengembangan situasi, tetapi perilaku adaptif memerlukan banyak usaha dan sering janggal. Orang pada tahap ini mengetahui apa yang dikatakan dan melakukan dalam variasi situasi budaya.

Tahap 4 : Asimilasi dari norma budaya beragam ke dalam perilaku alternative. Pada tahap ini, penyesuaian pada situasi yang berbeda tidak lagi memerlukan banyak usaha. Individu mengembangkan perilaku dari mana mereka dapat memilih tergantung pada situasi budaya spesifik.

Tahap 5 : Proaktivitas dalam perilaku budaya didasarkan pada pengakuan perubahan isyarat yang orang lain tidak merasa. Orang yang memiliki kecerdasan budaya tinggi mempunyai kemampuan merasakan perubahan dalam konteks budaya, kadang-kadang bahkan sebelum anggota budaya lain. Mereka sangat menyesuaikan diri pada nuansa interaksi interkultural sehingga mereka secara otomatis menyesuaikan perilaku untuk mengantisipasi perubahan ini dan memfasilitasi interaksi interkultural lebih baik satu sama lain.

Orang pada tingkat kecerdasan budaya yang lebih tinggi mempunyai persepsi yang kompleks terhadap lingkungan. Mereka mendiskripsikan orang dan kejadian dalam karakteristik yang berbeda dan dapat melihat hubungan diantara karakteristik tersebut.

Adapun proses pengembangannya adalah bahwa harus kita pahami bersama bahwa kecerdasan budaya mengandung tiga komponen, yaitu knowledge, mindfulness,dan behavior skill. Meningkakan kecerdasan budaya tidak merupakan proses linier, tetapi memerlukan pembelajaran melalui pengalaman yang cukup memerlukan waktu ( David, 2004 : 69).

Proses ini memerlukan tingkat dasar pengetahuan, penguasaan pengetahuan baru dan perspektif alternative melalui kesadaran, dan akomodasi serta asimilasi pengetahuan ini ke dalam keterampilan perilaku. Proses ini bersifat saling berhubungan dan dapat dipikirkan sebagai serangkaian kurva $S$ seperti di bawah ini:

Gambar Memperoleh Kecerdasan Budava

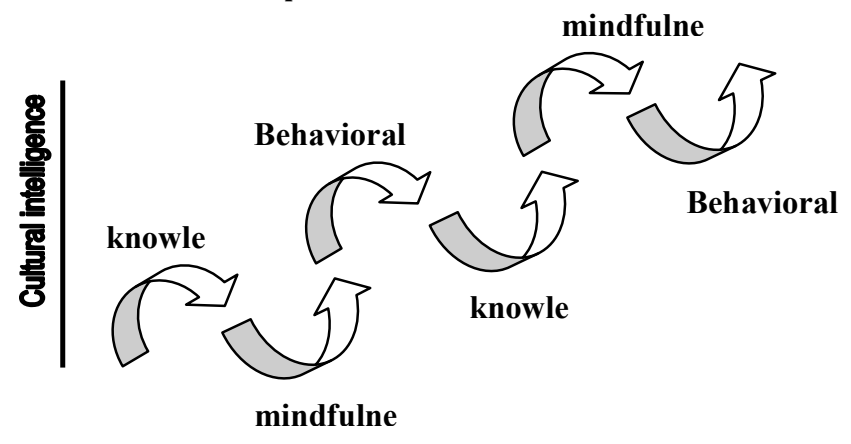

Penguasaan kecerdasan budaya menyangkut pembelajaran dari interaksi sosial. Pembelajaran sosial merupakan cara yang sangat kuat di mana pengalaman orang dipindahkan ke dalam pengetahuan dan keterampilan. Pembelajaran sosial menyangkut perhatian pada situasi dan ingatan dari pengetahuan yang diperoleh dari situasi, reproduksi dari keterampilan perilaku yang diamati, dan akhirnya penguatan tentang efektivitas dari perilaku yang disesuaikan. Kecerdasan memperbaiki budaya dengan belajar dari pengalaman sosial berarti memberi perhatian pada dan menghargai perbedaan kritis antara diri sendiri dan orang lain dalam budaya dan latar belakang.(Wibowo, 2013: 90).

Selanjutnya terdapat beberapa aktivitas yang dapat berperan penting untuk mengembangkan kecerdasan budaya antara lain yaitu (Wibowo, 2013: 92-94):

\section{a. Pendidikan formal/ Training} Terdapat tiga metode yang dapat dipergunakan untuk meningkatkan 
kecerdasan budaya. Metode factual menggunakan buku, kuliah atau ceramah. Metode analitikal menggunakan film, asimilator budaya, dan sensitivity training. Metode experiential menggunakan simulasi, kunjungan lapangan, dan bermain peran.

Diantara ketiga metode di atas, experiential training adalah paling efektif dalam mengembangkan kecerdasan budaya tinggi. Tetapi experiential training formal adalah jarang dan sering mahal. Karena itu untuk menjadi cerdas budaya, kebanyakan menggunakan interaksi dengan orang yang secara cultural berbeda.

b. Kelompok dan Tim Antarbudaya Pekerjaan yang dilakukan melalui kelompok dan tim kerja cenderung semakin meningkat. Di samping itu banyak orang terlibat dalam kelompok sosial dan kepentingan. Globalisasi menyebabkan kelompok terdiri dari orang yang berasal dari berbagai budaya.

c. Pengalaman Luar Negeri dan Penugasan Ekspatriat

Situasi paling menantang dimana dapat menghadapi perbedaan budaya adalah hidup dan bekerja di negara asing untuk sementara. Situasi ini juga menawarkan peluang untuk mendapatkan pembelajaran eksperimensial secara intensif.

d. Interaksi Antarbudaya di Dalam Negeri

Interaksi dengan pelayan restoran Cina merupakan interaksi antar budaya, tetapi dengan pengalaman yang sangat lunak dan kekurangan ikatan signifikan. Untuk menjadi lebih cerdas budaya perlu menantang dengan cara lebih dalam.

\section{Membangun Karyawan agar Memiliki Semangat Kompetisi yang Dinamis}

Seorang pemimpin harus mampu mengarahkan bawahannya untuk memiliki kompetensi dalam bekerja. Karena dengan kepemilikan kompetensi karyawan tersebut akan mampu mendorong peningkatan kualitas kinerja perusahaan maupun lembaga pendidikan. Kita bisa melihat perbedaan antara karyawan yang memiliki kompetensi dan yang rendah nilai kompetensinya, pada hasil kinerja yang mereka hasilkan ( Fahmi, 2014 : 88). Konsep kompetisi yang dinamis artinya membangun persaingan namun tetap dalam konteks yang fear atau positif, yaitu dengan persaingan yang ada mampu member dan membentuk kondisi kerja yang mengutamakan kepentingan perusahaan maupun lembaga dari pada kepentingan pribadi. Dengan begitu diharapkan visi dan misi organisasi akan tercapai. Karena salah satu faktor gagalnya pencapaian visi dan misi organisasi adalah disebabkan telah terbentuknya semangat persaingan yang bersifat individual demi kepentingan individual (Fahmi, 2014: 89).

Oleh karena itu jika kita kembali kepada konsep di atas maka berdasarkan pada gambar 3 dan 4 di bawah ini akan semakin bisa memperjelas pada kita tentang bagaimana peran pimpinan dalam membangun karyawan yang memiliki semangat kompetisi yang dinamis.

Gambar Peranan Pemimpin dalam Membangun Nilai Kompetensi pada Karyawan

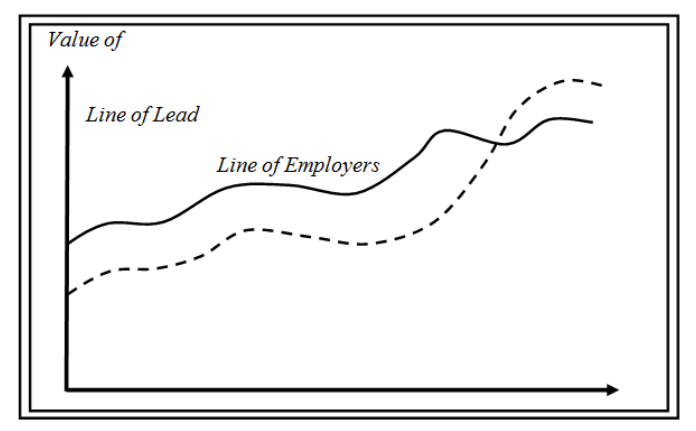


Gambar Kondisi Hubungan Pemimpin yang Tidak Membangun Nilai Kompetensi pada Karyawan

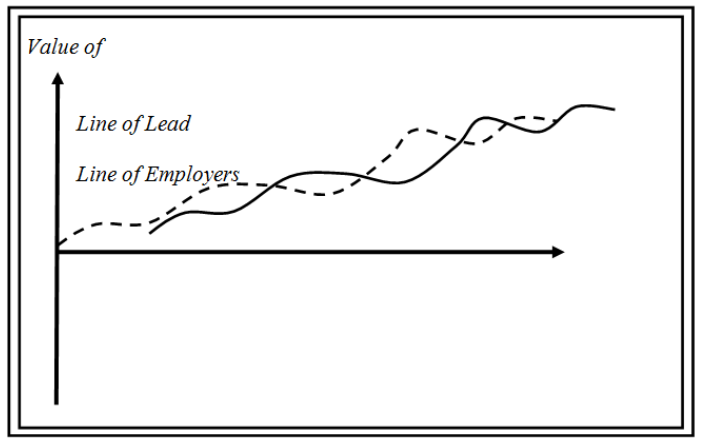

Pada gambar pertama memperlihatkan peran pimpinan yang begitu besar dalam mendukung dan membangun terwujudnya nilai kompetensi pada karyawannya. Dimana pimpinan pada akhirnya berhasil mengkaderkan karyawan untuk memiliki nilai kompetensi yang melebihi dari nilai kompetensi pimpinan. Sehingga pada posisi ini pimpinan dapat suatu saat menugaskan karyawan yang terpilih tersebut untuk menangani urusan-urusan penting bahkan mnegambil posisinya sebagai pimpinan di kemudian hari. Di mata investor perusahaan seperti ini dianggap mmeiliki tingkat kesolidan kuat dalam membangun dan mempertahankan kualitas kinerja keuangannya.

Artinya para investor sangat menyukai pemimpin yang memiliki sikap orientasi pada pengembangan. Pemimpin yang berorientasi pengembangan adalah pemimpin yang menghargai eksperimentasi, mengusahakan gagasan baru, dan menimbulkan serta melaksanakan perubahan (Robins, 2013: 45).

Adapun pada gambar yang kedua terlihat dimana pimpinan tidak memiliki kepedulian kuat dalam membangun terwujudnya nilai kompetensi pada diri karyawan. Sehingga dampaknya karyawan tidak pernah diberi dan memiliki kesempatan untuk menunjukkan kemampuannya. Dengan terjadinya kondisi seperti pada gambar yang kedua di atas ada beberapa dampak yang akan timbul pada saat seorang pimpinan menerapkan konsep seperti itu, yaitu :

a. Konstruksi manajemen lembaga pendidikan tidak memiliki nilai kompetensi secara jangka panjang.

b. Manajemen lembaga pendidikan dalam konteks pengambilan keputusan sangat tergantung pada apa yang ditugaskan atau diperintahkan oleh pimpinan.

c. Jika suatu saat ada kejadiankejadian tertentu yang bersifat tidak terduga, seperti pimpinan sakit, loss contact, dan sebagainya maka kondisi ini bisa mengganggu atau tertundanya berbagai aktivitas bahkan ini berdampak pada persoalan keputusan. Kondisi seperti ini bisa memunculkan vacuum of power ( kekosongan kekuasaan ), dan jika tidak segera di atasi maka bisa menimbulkan penurunan nilai perusahaan di mata publik.

d. Jika hal ini terjadi pada suatu perusahaan, di mata investor perusahaan seperti ini memiliki sisi rentan dalam konteks permasalahan keuangan di kemudian hari, khususnya kinerja keuangan. Dengan kata lain kondisi kinerja keuangannya memiliki nilai fluktuasi yang tinggi atau memiliki kelabilan yang tinggi. Yaitu akibat keputusan yang begitu sentralistis dan begitu kurang atau rendahnya kepercayaan pimpinan kepada karyawan.

\section{Meningkatkan Kecerdasan Emosi dalam Membangun Hubungan Kerja}

Secara psikologis, individu yang normal adalah individu yang memiliki integritas yang tinggi antara fungsi psikis (rohani) dan fisiknya (jasmaniah). Dengan adanya integritas yang tinggi antara fungsi 
psikis dan fisik, maka individu tersebut memiliki konsentrasi diri yang baik. Konsentrasi yang baik ini merupakan modal utama individu manusia mampu mengelola dan mendayagunakan potensi dirinya secara optimal dalam melaksanakan kegiatan atau aktivitas kerja sehari-hari dalam mencapai tujuan organisasi. Dengan kata lain, tanpa adanya konsentrasi yang baik dari individu dalam bekerja, maka akan menjadi sebuah mimpi bagi seorang pimpinan mengharapkan mereka dapat bekerja produktif dalam mencapai tujuan organisasi.Konsentrasi individu dalam bekerja sangat dipengaruhi oleh kemampuan potensi (kecerdasan pikiran/ inteligensi quotient/IQ, kecerdasan emosi/ emotional quotient/EQ dan kecerdasan spiritual/ $S Q$ ) ( Prabu, 2010: 36).

Hasil penelitian Daniel Goleman menyimpulkan bahwapencapaian kinerja ditentukan hanya 20 persen dari IQ, sedangkan 80 persen lagi ditentukan oleh kecerdasan emosi (EQ). Begitu pula disimpulkan oleh Joan Beck bahwa IQ sudah berkembang 50 persen sebelum usia 5 tahun, 80 persen berkembangnya sebelum 8 tahun, dan hanya berkembang 20 persen sampai akhir masa remaja; sedangkan kecerdasan emosi (EQ) dapat dikembangkan tanpa batas waktu. Oleh karena itu pimpinan jika mengharapkan pencapaian kinerja maksimal, upaya yang paling tepat bagaimana membina diri dan membina SDM bawahan untuk memiliki kecerdasan emosi baik (kecedasan emosi baik berarti mampu memahami diri dan orang lain secara benar, memiliki jati diri, kepribadian dewasa mental, tidak iri hati, tidak benci, tidak sakit hati, tidak dendam, tidak memiliki perasaan bersalah yang berlebihan, tidak cemas, tidak mudah marah dan tidak mudah frustrasi)

Hubungan relasi di tempat kerja perlu diciptakan agar iklim kerja dalam organisasi menjadi kondusif. Pimpinan dan bawahan perlu memahami bahwa mereka memiliki peran dalam menciptakan situasi yang penuh dengan pengelolaan emosi secara efektif. Pimpinan dan staf yang briliyan jika tidak memiliki keterampilan cara berkomunikasi efektif dan produktif dalam membangun hubungan kerja, maka mereka akan sulit mencapai tujuan organisasi.

\section{Meningkatkan Komunikasi dalam Menciptakan Hubungan Tim Kerja}

Pendekatan terbaik untuk mencapai kelompok kerja yang solid adalah pendekatan psikologis dengan teknik komunikasi persuasif melalui rumus AIDDAS.

$$
\begin{aligned}
& \text { A = Attention (perhatian), } \\
& \text { I = Interest (minat), } \\
& D=\text { Desire (hasrat), } \\
& D=\text { Decision (keputusan), } \\
& A=\text { Action (tindakan nyata), } \\
& S=\text { Satisfaction (kepuasan). }
\end{aligned}
$$

Pertama kali perlu dibangkitkan perhatian kepada karyawan (kelompok kerja) terhadap tujuan organisasi yang berhubungan dengan tugas yang harus segera dikerjakan agar timbul minat mereka, kemudian kembangkan hasratnya untuk mencapai target dengan komitmen (atasan dan bawahan). Setelah itu arahkan mereka untuk memutuskan (mengmabil keputusan bersama) untuk melakukan pekerjaan (proyek) dengan kerja keras dalam mencapai target group dengan harapan hasil kerjanya harus memberikan kepuasan bagi organisasi dan dirinya.

Langkah-langkah penggunaan pendekatan AIDDAS adalah sebagaimana berikut di bawah ini:

1) Berikan perhatian kepada karyawan dengan pendekatan komunikasi yang efektif dan menarik;

2) Pelajarilah terlebih dahulu kebutuhan, keinginan, perasaan, sifat dan ciri khas kepribadian karyawan;

3) Dengarkan dengan bijak pendapat karyawan dan kemudian berilah keyakinan 
mengenai tujuan organisasi (kelompok kerja) yang akan dicapai;

4) Manfaatkan rumus pendekatan AIDDAS dengan ekspresi muka yang meyakinkan dan menyenangkan (Prabu, 2010:4142).

\section{Kesimpulan}

Dalam menghadapi era globalisasi yang semakin bersifat kompetitif seperti sekarang ini, sebuah perguruan tinggi harus siap dan mampu menghasilkan lulusan atau out put yang bermutu dan siap pakai, untuk mencapai itu salah satu faktor pendukungnya adalah adanya pimpinan dan para dosen yang bermutu pula. Secara operasional peningkatan mutu kerja dosen harus dilakukan dengan pendekatan baru yaitu pendekatan kultural, oleh karenanya pimpinan perguruan tinggi dituntut untuk membangun budaya akademik dan etika keilmuan sehingga memberi pencerahan pada masyarakat kampus. Untuk mencapai itu dosen maupun karyawan perlu dibina melalui pengembangan budaya kerja sebagai satu peluang untuk membangun human resource development melalui penanaman nilai (value), keyakinan (belief), norma, pandangan, kebiasaan dan kepemimpinan untuk melakukan perubahan sikap dan perilaku yang diharapkan mampu menyesuaikan diri dengan tantangan yang sedang berjalan dan akan datang.

Budaya kerja adalah seperangkat perilaku perasaan dan kerangka psikologis yang terinternalisasi sangat mendalam dan dimiliki bersama oleh anggota organisasi. Budaya kerja merupakan suatu komitmen organisasi yang luas dalam upaya membangun sumber daya manusia, proses kerja, dan hasil kerja yang lebih baik. Untuk mencapai tingkat kualitas yang makin lebih baik tersebut diharapkan bersumber dari setiap individu yang terkait dalam organisasi kerja itu sendiri. Budaya Kerja lebih merupakan suatu proses yang tanpa akhir atau terus-menerus.
Kepemimpinan seseorang akan lebih efektif apabila didukung kondisi budaya kerja yang kuat. Dapat pula diartikan sebagai upaya pemimpin dalam mempengaruhi, merubah atau mempertahankan budaya kerja yang kuat untuk mendukung terwujudnya pencapaian tujuan, visi dan misi lembaga. Nilai keyakinan dan perilaku pemimpin menjadi bagian penting untuk melihat keefektifan kepemimpinan seseorang pada budaya kerja pada lembaga yang dipimpinnya. Itulah sebabnya bahwa pemimpin akan berupaya untuk membangun budaya kerja dalam organisasi didasari nilai, keyakinan dan perilaku yang dimilikinya.

Adapun beberapa strategi yang bisa ditempuh oleh pimpinan untuk peningkatan budaya kerja agar lebih dinamis dan kompetitif diantaranya adalah; (1)Menciptakan organisasi yang cerdas budaya, (2)Membangun karyawan agar memiliki semangat kompetisi yang dinamis, (3)Meningkatkan kecerdasan emosi dalam membangun hubungan kerja, dan (4)Meningkatkan komunikasi dalam menciptakan hubungan tim kerja.

\section{Daftar Pustaka}

Keputusan Mentri Pendidikan Nasional Republik Indonesia No. 232/U/2000 tentang PedomanPenyusunan Kurikulum Pendidikan Tinggi danPenilaian BelajarMahasiswa

Soehendro, Bambang. 1996. Kerangka Pengembangan Pendidikan Tinggi Jangka Panjang. Jakarta: Depdikbud Dirjend Dikti

Prawirosentono, Suyadi. 1999. Manajemen Sumber Daya Manusia; Kebijakan Kinerja Karyawan. Yogyakarta : BPFE.

Kasali, Rhenald. 2010. Manajemen Perubahan dan Manajemen Harapan. Jakarta: PT. Gramedia Pustaka Utama

Nawawi,Hadari. 2003. Manajemen Sumber Daya Manusia. Cetakan 
Kelima. Yogyakarta : Gajah Mada University Press.

Prasetya, Triguno. 2001. Manajemen Sumber Daya Manusia. Jakarta : Bumi Aksara

Ndraha, Taliziduhu. 2002. Teori Budaya Organisasi, Cetakan Kedua. Jakarta: PT. Rineka Cipta.

Koentjaraningrat. 1974. Kebudayaan, Mentalitet, Dan Pembangunan. Jakarta: PT. Gramedia.

Moedjiono,Imam. 2002. Kepemimpinan dan Keorganisasian. Yogyakarta: UII Press.

Asmani,Jamal Ma'mur. 2012. Tips Sakti Membangun Organisasi Sekolah,. Jogjakarta: Diva Press.

Triguno. 1999. Budaya Kerja; Menciptakan Lingkungan Yang Kondusif Untuk Meningkatkan Produktivitas Kerja, Jakarta: Golden Terayon Press

Subianto, Djarot. 2000. Budaya Kerja Era Digital. Jakarta: PPM Lembaga Manajemen.

Nawawi, Ismail. 2013. Budaya Organisasi, Kepemimpinan dan Kinerja, Proses Terbentuk, Tumbuh Kembang,Dinamika, dan Kinerja Organisasi. Jakarta: Kencana.

Sonhadji, Ahmad. 2012. Manusia, Teknologi, dan Pendidikan menuju Peradaban Baru. Malang: UM Press.

C. Handy. 2002. Understanding Organizations, (London : Penguin, 1985), dikutip langsung oleh Eugene McKenna dan Nic Beec, The Essence of : Manajemen Sumber Daya Manusia, Trj. Toto Budi Santoso.Yogjakarta: Penerbit Andi.
Prabowo, Sugeng Listyo. 2009. Implementasi Sistem Manajemen Mutu di Perguruan Tinggi. Malang: UIN Press.

Danim, Sudarwan. 2003. Menjadi Komunitas Pembelajar. Jakarta: Bumi Aksara.

Soekanto, Soerjono. 2003. Sosiologi suatu Pengantar. Jakarta: Grafindo.

Yukl, Gary. 2010. Kepemimpinan dalam Organisasi edisi kelima. Jakarta: PT. Indeks.

Soenarjo. Komitmen Pemimpin,Awal Keberhasilan Budaya Kerja, 2005 http://www.d-infokomjatim.gi.id/news.php?id=2494, Diakses tanggal 4 Oktober 2014.

Wibowo. 2013. Budaya Organisasi Sebuah Kebutuhan Untuk meningkatkan Kinerja Jangka Panjang. Jakarta: PT. Raja Grafindo Persada.

Thomas David C. and Kerr Inkson. 2004. Cultural Intelligence. San Francisco:Berrett-Koehler Publisher Inc.

Irham,Fahmi. 2014. Perilaku Organisasi, Teori, Aplikasi dan Kasus. Bandung: PT. Alfabeta.

Robbins, Stephen P. Timothy A. Judge. 2013. Organizational Behavior (Perilaku Organisasi) penerjemah Ratna Saraswati. Jakarta: Salemba Empat.

Mangkunegara, Anwar Prabu. 2010. Perilaku dan Budaya Organisasi. Bandung: PT Refika Aditama. 